УДК 78.03+784/78.085.24

О. Муравская

\title{
ХОРОВЫЕ ПОЛОНЕЗЫ О. КОЗЛОВСКОГО В КОНТЕКСТЕ ТРАДИЦИЙ АЛЕКСАНДРОВСКОГО АМПИРА
}

Статья посвящена рассмотрению поэтики хоровых полонезов О. Козловского, характеризующихся в русле специфики русской музыкальноисторической традици рубежа ХVIII-ХIX столетий и стилевых качеств Александровского ампира.

Ключевые слова: ампир, Александровский ампир, имперская придворная культура, полонез, хоровой полонез, творчество О. Козловского.

«Искусство ампира - самая блистательная эпоха русской культуры. Его художественное совершенство и философская глубина очевидны, величественность форм, благородство пропорций, гармония и мощь притягивают к себе», - констатировал в своем фундаментальном исследовании о данном стиле А. Гайдамак. Отмечая далее его популярность в культуре всей Европы начала ХІХ столетия, названный автор вместе с тем указывал, что «свое самое совершенное воплощение этот стиль нашел в России. Великая радость победы в войне 1812 года окрасила русский ампир в ликующие и праздничные тона, придав этому воинственному и мужественному стилю романтический оттенок» [4, с. 5].

Исторические рамки бытия ампира в русской культуре чаще всего определяют на уровне, прежде всего, первых десятилетий XIX века, связывая его расцвет с эпохой царствования Александра I («Александровский ампир»). Вместе с тем данный стиль принято также идентифицировать и с завершающей стадией русского классицизма (позднего классицизма), с которым его связывает ряд общих признаков - «композиционная симметрия, ясность и четкость линейного рисунка, скульптурная объемность предметов» [3, с. 4], апеллирование к античной тематике, ее символике и т. д. Одновременно ампир характеризуется целым рядом признаков, отличающих его индивидуальность, равно как и породившая его эпоха великих империй (Россия, Франция).

Символика и атрибуты античной культуры вступали в Александровском ампире в органическое взаимодействие со «знаками» русской национальной культуры и ее историческими реалиями. Иной существенной чертой этого стиля выступает его ярко выраженное

(C) Муравская O., 2016 
духовное соборное начало, во многом обусловленное русской имперской идеей, концепцией теократии, ориентированной на преемственность, трансляцию и сохранение православной традиции, сакрализирующей не только церковную жизнь, но и быт и культуру императорского двора.

Тема «ампир и музыка», в том числе применительно к русской музыкальной культуре конца XVIII - начала XIX столетий, в настоящий момент пока не стала предметом фундаментальных музыкально-культурологических изысканий, в отличие от иных сфер художественной деятельности (архитектура, скульптура, декоративно-прикладное искусство, живопись, поэзия и др.), в рамках которых стилистика ампира изучена достаточно основательно. Востребованность в современной исполнительской и исследовательской практике музыкальных сочинений репрезентантов эпохи Александровского ампира обусловливает актуальность темы представленной статьи, предмет которой ориентирован на исследование поэтики хоровых полонезов О. Козловского как одного из наиболее ярких представителей названной эпохи и ее «имперского стиля».

Исследование данной проблематики в отечественном музыкознании чаще сопряжено с изучением музыки обозначенной эпохи в связи с бытом, а также церемониальной культурой русского императорского двора. Среди работ последних десятилетий особо выделяем докторскую диссертацию Н. А. Огарковой «Музыка как феномен церемониальной и повседневной жизни русского двора XVIII - начала XIX века» (2004), цель которой обозначена автором на уровне «реконструкции практики музыкального оформления государственных церемоний и праздников русского двора и выявления форм музыкального досуга русской аристократии, определения их роли в жизни общества» $[11$, с. 4]. Затрагивая творчество русских композиторов рубежа XVIII-XIX столетий, привлекая массу фактологического и исторического материала по обозначенной проблематике, исследователь вместе с тем не затрагивает вопрос о связи их наследия со стилевыми качествами ампира.

Сказанное, в частности, соотносимо и с творчеством О. Козловского, который, по меткому определению Б. Асафьева, «...от барокко отошел и приближался к величию ампира в своих маршах, шествиях, молитвах и величаниях, сурово-сдержанных, без излишней пышности четко скомпанованных» [2, с. 120]. Библиография, посвященная данному автору, невелика. Помимо цитированной выше статьи 
Б. Асафьева, отметим очерки Ю. Келдыша [8], П. Грачева [6], а также материалы, представленные в IV томе «Истории русской музыки» [7]. По мнению авторов последнего издания, творчество О. Козловского стилистически занимает промежуточное положение между классицизмом и романтизмом. Ссылаясь на наблюдения опять-таки Б. Асафьева, исследователи отмечали, что «порожденная революционным и героическим духом времени, его музыка наполнена новым ощущением глубоких перемен и тревожных ожиданий», «мужественно-героическим пафосом», «пафосом печали пламенного порыва», «суровой покорностью» и «пылким рыцарским возбуждением» [7, с. 93], что соотносимо и с образно-смысловыми характеристиками ампира.

Связь композитора с данным стилем во многом определена особенностями его биографии и творческого пути. Поляк по национальности, О. Козловский (1757-1811) вместе с тем связал свою жизнь с Россией. Начав свою композиторскую деятельность еще в конце XVIII века, он приобрел громкую известность как автор «российских песен» и множества полонезов, как создатель первого в России Реквиема (на латинский текст). В дальнейшем он выдвинулся в области театральной музыки, проявив при этом высокое мастерство симфониста.

Условия его творческой деятельности были достаточно своеобразными и во многом обусловлены спецификой бытования музыки как искусства в рамках имперской России конца XVIII - начала XIX столетий. Приехав в Россию почти в тридцатилетнем возрасте с устоявшимися взглядами и определенным профессиональным опытом, О. Козловский, тем не менее, сразу же уловил сущность тех жанрово-стилевых процессов, которые имели место в музыкальнообщественной и культурной жизни его новой родины в названный период. Пользуясь покровительством всесильного князя Г. А. Потемкина, музыкант проник в среду петербургской аристократии и приобрел известность в придворных кругах, а также и расположение императорской фамилии. «Естественно, что такая ориентация в какой-то мере направляла и творческую деятельность композитора, в силу обстоятельств вынужденного работать в области официальной музыки празднеств, так называемой «musique d'occasion». В его обязанности входило «обслуживание» придворных торжеств - как общегосударственного характера (например, победы русского оружия), так и камерных вечеров» [7, с. 92-93].

«Прикладной» и подчас репрезентативный характер подобной деятельности вместе с тем не был для О. Козловского препятствием на 
пути к созданию ярких сочинений, запечатлевших дух его героической эпохи и имперских идей страны, ставшей для него второй родиной. Подтверждением сказанного можно считать славу, признание и успех, которые неизменно сопутствовали ему на протяжении большей части его жизненного пути. «Судя по сделанной Козловским карьере, профессионализм достаточно высоко ценился при дворе и в среде аристократии. Но на титульных листах своих рукописных и издававшихся сочинений Козловский, определяя свой статус, подписывался «amateur» [11, с. 154].

Тем не менее, статус «аматора» не помешал О. Козловскому стать одним из видных представителей русской музыкальной культуры рубежа веков, чье имя стоит в одном ряду с высокопрофессиональными авторами данной эпохи. Б. Асафьев проводит любопытные параллели между творческими личностями Сарти и Козловского, для которых именно Россия оказалась местом реализации их таланта. «Первый [Сарти] мягче в звучании, стройнее и яснее в композиции и щедрее на пышную орнаментику, яркий представитель музыкального барокко. Второй - мужественный, темпераментный, рыцарственно-горделивый, терпкий даже там, где складывается наступивший сентиментализм, более смелый в замыслах, но зато и более неуравновешенный. Но удивительным образом... Сарти и Козловский подчинялись велениям новой родины и «трансформировали» свои дарования и приемы композиции в желательном ей смысле, как это уже давно до них случалось со строителями кремлевских соборов и как происходило и при них» [2, с. 120].

Продолжая мысль исследователя, отметим, что наследие названных авторов в данном случае оказалось удачно «вписанным» в русскую имперскую культуру и ее базовые идеи, определившие в конечном итоге жанрово-стилевые «доминанты» их творчества. В этом плане композиторская деятельность О. Козловского у современников и потомков, прежде всего, ассоциируется с жанром полонеза. Композитор обращался к нему на протяжении всего своего творческого пути: первые сочинения этого жанра относятся к 1790-м годам, а последние полонезы датируются 1818 годом. Большинство биографов и исследователей творчества О. Козловского солидарны в том, что данный жанр в творчестве композитора отличается предельным образно-смысловым и стилевым разнообразием - от парадно-репрезентативного танца до его камерно-лирического аналога, что обусловлено не только его поэтикой и семантикой, но и спецификой 
бытования в рамках собственно русской культуры рубежа XVIII-XIX столетий.

Полонез - один из наиболее популярных танцев Европы. Возникнув в Польше, о чем свидетельствует его название, он активно ассимилировался и в других странах, в том числе в России. Согласно выводам Е. Солениковой, «первые танцы под общим названием «польские танцы» известны с 1544 г., но интересно отметить, что так их называют только иностранные источники, в самой Польше такие названия неизвестны» [13]. Его аналог здесь чаще именовался как «ходзоный» («ходимый», «вышагиваемый») [12]. Еще одним предком полонеза, был «танец великий», описанный как торжественное шествие - по характеру он очень напоминал полонез в том виде, в котором он будет известен в начале XVIII в. По мнению авторов XIX в., истинный старопольский его вариант «танцевался только мужчинами и приобрел черты уверенной, воинственной горделивости... Это был торжественный танец, выражавший рыцарские идеалы шляхты: уверенность в своих силах, восхищение своей прекрасной дамой, независимость, горделивость» [13], соотносимые, на наш взгляд, и с идеями величия Польши как могущественного государства, имевшего до определенного момента колоссальный политический «вес» в европейском ареале.

Со временем полонез приобрел популярность во всей Европе. Его известность особенно возрастает к началу 1790 -х годов и устойчиво сохраняется до 1830 года. Полонезы писались для балов и маскарадов, посвященных официальным церемониям двора, салонного и домашнего музицирования. Как правило, сначала они создавались для оркестра, а затем наиболее популярные из них перекладывались авторами для различных исполнительских составов в расчете на удовлетворение вкусов любительско-музицирующей аристократической аудитории.

При всем разнообразии темброво-исполнительских интерпретаций полонеза данный танец на протяжении столетий сохранял присущую ему изначально торжественность и репрезентативность как «единственного танца, достойного монархов и сановных особ» [9]. Наиболее полно семантика данного танца обобщена в книге Ф. Листа, посвященной Ф. Шопену. По его словам, «полонез вовсе не был банальной и бессмысленной прогулкой; он был дефилированием, во время которого все общество, так сказать, приосанивалось, наслаждалось своим лицезрением, видя себя таким прекрасным, таким 
знатным, таким пышным, таким учтивым. Полонез был постоянной выставкой блеска, славы, значения. Епископы, высшие прелаты, церковники, люди, поседевшие в сражениях или в состязаниях в красноречии, военные, чаще носившие кирасу, чем одежду мирного времени, высокие государственные сановники, престарелые сенаторы... были желанными, излюбленными кавалерами в танцах; их оспаривали самые молодые, блистательные женщины, менее суровые в моменты таких эфемерных выборов, когда заслугам и сану отдавалось предпочтение перед молодостью... Из того, что нам рассказывали о забытых эволюциях и фигурах этого величавого танца старины люди, не желающие доныне расставаться со старинными жупанами и кунтушами ... мы узнали, насколько врожден был этой гордой нации инстинкт представительства, как глубоко была в них заложена эта потребность и как поэтизировали они эту склонность к парадности благодаря присущему им по природе гению изящества, сообщая ей отблеск благородных чувств и обаяние высоких побуждений» [10, с. 16-17]. В приведенной характеристике очевидна не только фиксация через специфику полонеза собственно польского этнического качества, но и социального аспекта, в рамках которого данный танец символически представительствует от имени высшего сословия в иерархическом обществе, демонстрируя его лучшие духовно-этические качества.

Закономерным в связи с этим выступает особая популярность данного танца, прежде всего, в странах, где господствовал монархический принцип правления. Здесь полонез обретал не только смысл репрезентативного танца высшей знати, но и становился символом духовного и государственно-политического величия страны. Отметим также, что репрезентативность полонеза во многом была определена его древнехристианским генезисом, поскольку торжественная форма шествия как базовый принцип его исполнения, по мнению Т. А. Акиндиновой и А. В. Амашукели, «была задана традицией богослужебного шествия» [1, с. 123-124]. Так величаво-торжественные полонезы Ф. Шопена, воплотили историческую и духовную память о былом величии Польши. Парадные же полонезы О. Козловского были порождены реальностью имперского величия Российского государства, унаследовавшего и воплощавшего в реальной исторической практике идею «симфонии властей».

Для поляка О. Козловского обращение к данному жанру, с одной стороны, символизировало связь с родиной. С другой стороны, полонез, утвердившийся в церемониальной жизни русского импера- 
торского двора еще в XVIII в., стал органичной частью собственно русской культуры, вобрав в себя ее характерные особенности. Изучая специфику бытования полонеза в России, многие исследователи неоднократно отмечали характерный синтез его типологии с виватными и панегирическими кантами и близкими к ним жанрами, знаменовавший слияние инструментализма и столь показательного именно для русской культуры вокально-хорового начала. Исследуя жанровую природу церемониальной и повседневной жизни русского императорского двора времен Елизаветы и Екатерины II, Н. А. Огаркова отмечает, что «шествия императриц озвучивали канты в жанре полонеза. Мужской хор, достаточно внушительный по составу (40 человек), мощными голосами встретив императрицу у Успенского собора или триумфальных ворот, влившись в процессию, сопровождал ее далее. И шествие под пение многострофного славильного канта приобретало характер некоего ритуального таниа, что сообщало литературным текстам характер особой торжественности и помпезности. Как нам удалось установить, сопоставив источники, такую функцию выполняли в коронационных шествиях Елизаветы Петровны канты-полонезы «Приспе день красный, возсияло ведро», «Гряди наш свет, Елисавет», «Виват преславна самодержавна». Полонез «Воспой торжественно, Россия, возвыси до небес свой глас» звучал во время шествия Екатерины в Успенский собор в день церемонии ее торжественного въезда в Москву. Кант «Гряди, дражайша наша мати» вполне мог использоваться в шествиях и открывать церемониальные балы» [11, с. 106].

В России, благодаря стараниям О. Козловского, особенное распространение получил хоровой полонез, что не удивительно для страны с развитой церковно-певческой культурой. Хоровые полонезы открывали церемониальные балы, символизируя важность исторического момента, значение и устойчивость императорской власти. Хор в сочетании с симфоническим и роговым оркестрами, создавал особую атмосферу помпезности и подчеркнутой гимничности. Выполняя многочисленные заказы на «музыкальное оформление» празднеств, открывавшихся, как правило, полонезом, О. Козловский в соответствии с духом времени развивал в России традицию панегирического искусства, в полной мере соответствовавшего мощи и величию российского государства и его духовно-имперской идеи, в соответствии с которой светская придворная традиция обретала сакральные качества. 
К числу наиболее значительных хоровых полонезов композитора принадлежат сочинения, исполненные на потемкинском празднике по случаю взятия Измаила (1791): «Гром победы, раздавайся» (на тексты Г. Державина), «Возвратившись из походов» и «Самодержица народов». Позднее были созданы полонезы: «Звук оружиев бессмертных» (1792), «Торжествуй, Твоя то воля» (на тексты Нелединского-Мелецкого, 1796), «Росскими летит странами» (на тексты Г. Державина, 1801). Последнее произведение было создано по случаю коронации Александра I. В числе более поздних произведений данного жанра выделяется «Польский с хором на победы светлейшего князя Михаила Ларионовича Голенищева-Кутузова Смоленского, спасителя отечества» (текст Н. Николева, 1813).

Очевидно, что парадно-торжественные хоровые полонезы явились своеобразным откликом О. Козловского на знаменательные события государственной жизни Российской империи. Индивидуальность замысла каждого из названных произведений вместе с тем не исключает общности их выразительных приемов, в числе которых - фанфарные обороты-зовы, яркие динамические контрасты, очевидное доминирование туттийных эпизодов, чередование аккордового типа фактуры с унисонами. Однако, «несмотря на преобладание типизации и известную ограниченность содержания парадных полонезов, в творчестве Козловского они сыграли немаловажную роль: в них складывался монументальный хоровой стиль, вырабатывались принципы симфонического мышления композитора, они повлияли также на хоровые сцены и увертюры его театральной музыки» [7, с. 98].

Обозначенная обобщенность музыкального выражения в хоровых полонезах О. Козловского, весьма показательная для имперского типа культуры, вместе с тем не исключает использования в данных сочинениях интонационно-мелодического материала известных произведений других авторов. Анализируя коронационные «сюиты» О. Козловского, состоящие, главным образом, из полонезов, Н. А. Огаркова отмечает, что большинство из них написаны на мелодии популярных в музыкальном быту того времени произведений. «В «сюите» на коронацию Павла Петровича в специфически танцевальной ритмике польского танца преломляются следующие темы: арии из оперы Дж. Паизиелло «Didone abbandonata» («Покинутая Дидона», второй полонез - Es-dur), дуэтов И. Плейеля (третий - B-dur, шестой B-dur), главной партии увертюры из «Волшебной флейты» Моцарта (четвертый - Es-dur), арии из оперы Ф. Бианки «La villanella rapita» 
(«Похищенная крестьянка», пятый - D-dur). B сюите на коронацию Александра I звучат темы: итальянской арии «Tu me dame dividi» (третий полонез - g-moll), французских романсов П.-А. Монсиньи Ж. Ф. Лагарпа «O, ma tendre musette» («O, моя нежная свирель», трио третьего полонеза - g-moll), Козловского - Ж.-П. Флориана «Je vais done quitter pour jamais» («Я покидаю навсегда мою пастушку дорогую», пятый - As-dur), квинтета, рондо и серенады Плейеля (второй полонез - a-moll, третий менуэт - G-dur, четвертый полонез - Esdur)». Известен также факт обращения О. Козловского в одном из своих полонезов к тематизму оперы «Весталка» Г. Спонтини, как к одному из репрезентантов французского музыкального ампира наполеоновской эпохи [11, с. 145, 153]. Подобного рода практика отчасти сближает полонез с транскрипцией и парафразой. При этом тематизм иных авторов оказывается в рамках подобного сочинения «облеченным» в метро-ритмические и фактурные «одежды» полонеза - жанра-символа духовного величия империи и ее военных побед.

Классическим образцом произведений подобного рода можно считать знаменитый полонез О. Козловского «Гром победы, раздавайся». Энергичная музыка этого произведения полна патриотического пафоса и подъема. Доминируют восклицательные фанфарные интонации, тутти оркестра, могучие унисоны, яркая динамика, что в совокупности передает настроение общего ликования. Средняя часть полонеза, более камерная по фактуре и оркестровке. Тем не менее, благодаря использованию пунктирной ритмики музыка трио все же сохраняет внутреннюю энергию начального образа. По мнению В. Н. Грачева, «церемониальный танец-шествие полонез оказался тем жанром, который прекрасно подошел для музыкального воплощения идеи великой победы русского оружия... Одновременно в интонациях полонеза были заметны элементы церковной музыки: прослушиваемая в медленном темпе мелодия раскрывала свою юбиляционную природу. Ассоциацию с богослужебным напевом вызывал также хорально-аккордовый склад фактуры и псалмодическая однотонная интонация в начале некоторых фраз» [5]. В обозначенной интонационной характеристике данного произведения очевидны не только стилевые качества творчества О. Козловского, но и типология собственно русского ампира, в рамках которого имперская идея «Третьего Рима» была неотделимой от духовно-соборного начала.

Колоссальный успех хорового полонеза «Гром победы, раздавайся» снискал ему славу одного из гимнов российской империи в XIX ст. 
Сказанное подтверждает не только высокую значимость творческого наследия О. Козловского, но и резонансность в рамках русской культуры хорового полонеза как высокого «знака» имперской (ампирной) культуры. Типология полонеза, духовной певческой хоровой традиции вступает в данном сочинении также во взаимодействие и с поэтикой гимна.

Популярность анализируемого хорового полонеза О. Козловского проявлялась не только в достаточно частом его использовании в официальной придворной практике конца XVIII - начала XIX ст., но и в цитировании его заглавной темы в аналогичных произведениях иных авторов. Так в III части оратории С. Дегтярева «Минин и Пожарский» в один из кульминационных моментов (№ 21) звучит хор, буквально воспроизводящий тему полонеза О. Козловского. При этом текст данного хора соотносим с духовно-смысловой сущность русской имперской идеи: «Чти престол, законы, правду, веру чистую храни. Побеждай в морях, на суше и полсветом обладай».

Символичен также и тот факт, что уже во второй половине XIX ст. П. И. Чайковский использовал музыку славильного припева из «Полонеза» О. Козловского в конце третьей картины оперы «Пиковая дама» в сцене появления на балу императрицы Екатерины II. Данный музыкальный материал не только живописует имперскую Россию XVIII ст. (куда собственно, в отличие от повести А. С. Пушкина, и переносится время действия оперы), но составляет очевидный контраст по отношению к драме ее главного героя.

Итак, ампирное качество парадных полонезов О. Козловского, в частности, хорового полонеза «Гром победы, раздавайся», ставшего неофициальным гимном Российской империи, формировалось на стыке типологий двух жанров, каждый из которых сам по себе был средоточием ярких выразительных «имперских» качеств. С одной стороны, имперская идея здесь запечатлевалась через опору на жанр гимна, имеющего глубокие духовные генетические корни в христианской богослужебно-певческой традиции, в виватных и панегирических кантах петровской эпохи. С другой стороны, гимническая поэтика в обозначенных произведениях О. Козловского существенно дополняется опорой на традиции полонеза, генетически также восходящего к христианской традиции богослужебного шествия и ставшего позднее одним из знаков сакрального качества имперской придворной культуры и ее стиля (ампир). 


\section{СПИСОК ЛИТЕРАТУРЫ}

1. Акиндинова Т. Танец в традиции христианской культуры / Т. А. Акиндинова, А. В. Амашукели. - СПб. : Издательство РХГА, 2015. - 239 с.

2. Асафьев Б. Памятка о Козловском / Б. Асафьев // Музыка и музыкальный быт старой России: на грани XVIII и XIX столетий : [сб. работ исторической секции О. Т. И. М.]. - Л. : Academia, 1927. - С. 117-122.

3. Бедретдинова Л. Александровский ампир / Л. М. Бедретдинова. - М. : Белый город, 2008. - 48 с.

4. Гайдамак А. Русский ампир / А. Гайдамак. - М. : Трилистник, 2006. - 167 с.

5. Грачев В. Государевы гимны [Электронный ресурс] / В. Н. Грачев. - Режим доступа : www.portal-slovo.ru/art/36044.php

6. Грачев П. О. А. Козловский / П. В. Грачев // Очерки по истории русской музыки: 1790-1825 / [под ред. М. С. Друскина, Ю. В. Келдыша]. - Л. : Государственное музыкальное издательство, 1956. - С. 168-216.

7. История русской музыки : в 10 томах / [редколлегия: Ю. В Келдыш, О. Е. Левашова и др.]. - М. : Музыка, 1986. - Том четвертый : 1800-1825. — $416 \mathrm{c}$.

8. Келдыш Ю. Полонезы Юзефа Козловского / Ю. Келдыш // Очерки и исследования по истории русской музыки. - М. : Советский композитор, 1978. - C. 141-158.

9. Кулакова М. Полонез. История танца. Основные особенности [Электронный ресурс] / М. С. Кулакова. - Режим доступа: https://festival.1september. $\mathrm{ru} /$ articles/55324/

10. Лист Ф. Ф. Шопен / Ф. Лист. - М. : Государственное музыкальное издательство, 1956. - $126 \mathrm{c.}$

11. Огаркова Н. Музыка как феномен церемониальной и повседневной жизни русской двора. XVIII - начало XIX века : дис. ... доктора искусствоведения : 17.00.02 - Музыкальное искусство / Н. А. Огаркова. - СПб. : Российский институт истории искусств, 2004. -613 с.

12. Полонез [Электронный ресурс]. - Режим доступа: https://ru.wikipedia. org/wiki/полонез

13. Соленикова Е. Полонез. История танца [Электронный ресурс] / Е. Соленикова. - Режим доступа : https : historicaldance.spb.ru/index/articles/ general/nid/33243

Муравська О. Хорові полонези Й. Козловського в контексті традицій Олекcaндрівського ампіру. Стаття присвячена розгляду поетики хорових полонезів Й. Козловського, що розглядаються у річищі специфіки російської музичноісторичної традиції рубежу XVIII-XIX століть та стильових якостей Олександрівського ампіру.

Ключові слова: ампір, Олександрівський ампір, імперська придворна культура, полонез, хоровий полонез, творчість Й. Козловського. 
Muravskaya $O$. Choral polonaises $O$. Kozlovsky in the context of the tradition of Alexander's empire. The article is devoted to the poetics of choral polonaises O. Kozlovsky considered in line with the specifics of russian musical and historical tradition of the turn of XVIII-XIX centuries and stylistic qualities of Alexander's empire.

Keywords: empire, Alexander the empire, the imperial court culture, polonaise, choral polonaise, creativity O. Kozlovsky.

Стаття надійцла до редакції 13.04.2016

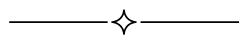

УДК $78.03+781.6$

\author{
Ю. Грибиненко
}

\title{
СОНАТА ДЛЯ ВИОЛОНЧЕЛИ И ФОРТЕПИАНО № 1 АЛЬФРЕДА ШНИТКЕ В КОНТЕКСТЕ ЭВОЛЮЦИИ АВТОРСКОГО СТИЛЯ
}

Статья посвящена рассмотрению образно-смысловых, композиционно-драматургических и жанрово-стилевых особенностей первой виолончельной сонаты А. Шнитке в контексте эволюции его композиторского мышления. Акцентируется внимание на драматургических приемах, спеиифике и диапазоне языковых средств, на особенностях трактовки выразительных возможностей инструментов, на образном строе сочинения, как этапного на новом витке эволюции авторского стиля композитора.

Ключевые слова: виолончельная соната, А. Шнитке, интонационное единство, моностилистика, пауза.

Первая виолончельная соната (1978), посвященная Наталии Гутман ${ }^{1}$, стоит в центре камерно-инструментального творчества А. Шнитке. Ее отделяет десятилетие от написания Второй скрипичной сонаты, девять лет от Первой фортепианной и шестнадцать от Второй виолончельной. Сам композитор, неоднократно высказывавшийся по поводу своего творчества, дал следующую характеристику своей первой виолончельной сонате, впервые прозвучавшей на авторском вечере А. Шнитке 29 марта 1979 года: «Это очень простое сочинение, и никаких особенных технологических замыслов у меня не было. Единственное, что обращает на себя внимание - то, что мне

\footnotetext{
${ }^{1}$ Как известно, кроме сонаты, композитор посвятил этой исполнительнице (как называл ее С. Рихтер, «цветок с корнями дуба») также свой концерт для виолончели с оркестром № 1 (1986).
}

(C) Грибиненко Ю., 2016 